\title{
The revenue implications of trade liberalization in Tanzania
}

\author{
Manamba Epaphra \\ Department of Accounting and Finance, Institute of Accountancy Arusha, Arusha, Tanzania
}

\section{Email address:}

emalugu_007@yahoo.com

\section{To cite this article:}

Manamba Epaphra. The Revenue Implications of Trade Liberalization in Tanzania. Journal of World Economic Research. Vol. 3, No. 3, 2014, pp. 25-36. doi: 10.11648/j.jwer.20140303.12

\begin{abstract}
This paper examines the argument that trade liberalization depresses the import duty revenue, and consequently adversely affects the total tax revenue. The study is thought to be significant because Tanzania experiences difficulty in replacing import duty revenue loss as a consequence of trade reform by strengthening its consumption tax system. In the course of analysis, cointegration analysis and error correction modelling are employed over the 1979/80-2009/10 period. The empirical results show that import duty revenue-to-GDP ratio is positively related to tariff rates, implying that a reduction in the tariff rates results in a significant loss of import duty revenue. The results also show that the removal of protectionist policies led to an increase in import-to-GDP ratio which in turn led to rising shares of import duty revenue in GDP. Finally, the results generate some policy implications. The proper issue in tax design under trade liberalization, Tanzania needs to strengthen the domestic tax system and raise tax revenue without increasing tax rates by reinforcing tax and customs administrations so as to maintain fiscal stability.
\end{abstract}

Keywords: Imports, Import Duty Revenue, Trade Liberalization, Tanzania

\section{Introduction}

Many representatives of development institutions and most academics believe that trade liberalization, combined with other economic and structural reforms, stimulate competition, enhance productivity, and accelerate economic growth. Research by the World Bank, for example, shows that per capita income in developing countries integrating rapidly into the global economy grows more than three times as fast as in other developing countries (Dollar and Kraay, 2001). Rapid growth in many Latin American countries in the late 1980s and 1990s came about with domestic policy liberalization and open-economy models, which reduced trade barriers. There is therefore, a wide and growing consensus regarding the need for all countries especially developing countries, to adopt a liberalized trade regime.

Tanzania being a member of World Trade Organization (WTO) could not avoid the increased global integration. However, a significant concern, as it contemplates further trade liberalization, is the potential impact of trade liberalization on tax revenues, and the core issue being its ability to substitute domestic sales taxes such as VAT and excise taxes for import duties. Trade liberalization is most likely to pose serious fiscal problems to Tanzania as it relies on international trade taxes for a large share of its total revenue.

Trade liberalization involves progressive elimination of tariffs and at the limit may push trade tax revenue to zero. Available evidence from previous studies suggests that revenue recovery has been a real issue for many developing countries. At best, they have on average recovered no more than 30 cents of each lost dollar (Baunsgaard and Keen, 2005). This explains in part the hesitance of many countries to undertake trade liberalization and the limitations to their sustainability.

Many developing countries have implemented trade reforms while avoiding significant revenue losses. The prospects for further trade liberalization are likely to depend in part, on the extent to which they will cause trade tax revenue to decline further and whether countries are able to deal with such revenue losses. Arguably, the IMF and World Bank have until now in almost all cases pressed trade liberalization up on low-income countries as part of structural adjustment by asking for the removal of tariffs. Thus, the main issue should not be the reduction of revenue from trade but of total tax revenue. If the fall in the trade 
taxes had been easily compensated by increase in other taxes, most obviously by strengthening domestic indirect taxes, then these would not be a problem. Tanzania is a good case study to analyze these challenges since Tanzania's reliance on international trade taxes remains higher, relative to many other sub-Sahara African countries (DiJohn, 2010).

The main objective of this paper is to examine the impact of trade liberalization on import duty revenue in Tanzania. Specifically, the study aims at examining the effect of trade liberalization-proxied by a decline in collected tariff rates and accompanying macroeconomic changes such as exchange rate, per capita GDP and imports on import duty revenue. It also examines the relationship between import duty revenues and domestic tax revenues (domestic consumption taxes and income taxes) to uncover whether Tanzania can replace import duty revenue loss from domestic sources.

The study is important because there has been relatively little empirical research on the impact of trade liberalization on tax revenue in Tanzania. Studies of the extent to which import duty revenue responds to trade liberalization and that lost trade tax revenues have been recovered from domestic sources reach somewhat different conclusions, reflecting differences in countries and time samples, methodologies and in the source of the revenue data. The study fills this gap in information by piecing together empirical evidence on some aspects of the Tanzanian tax system.

Tanzania has committed itself to a process of trade liberalization in the framework of the World Trade Organization. It is therefore, important to anticipate the impact of trade liberalization on tax revenue and take the necessary actions in a timely fashion if it is concluded that the impact could be significant. These issues need to be related to the specific circumstances of Tanzania. General answers as provided by previous studies in other countries are not likely to be very helpful for Tanzania since the structure of the economies, the sophistication of the tax administrations; or political obstacles vary across countries.

\section{Tax Revenue Concerns of Trade Liberalization}

Tanzania expresses concern that eliminating tariffs for non-agricultural products would trigger fiscal instability because of its high reliance on tariffs as source of revenue. Because tariff receipts are collected at specific locations (i.e. customs clearance points), they are generally considered to benefit from lower collection costs than most other taxes. This might explain why despite their sub-optimality tariffs are frequently used as revenue device by low-income countries (Aizenman, 1985). In Tanzania, the share of import tax revenue in total tax receipts in 1993-2005 amounted to more than 25 percent. Africa as a whole, international trade taxes generate on average 28 percent of total current revenues over the last decade (UNECA, 2004). This compares to 0.8 for high-income Organization for
Economic Cooperation and Development (OECD), and 23 percent for low-income countries (UNECA, 2004).

Recognizing that trade reform is vital to economic development and poverty reduction; developing country policymakers have lowered tariffs, and reduced non-tariff barriers, the argument being that when tariffs are very high or prohibitive, products may be under-invoiced, smuggled, or not imported (Amponsah, 2002). When tariffs are reduced to reasonable rates, products are more likely to enter a country through formal means and have duties paid on them. This may increase overall revenue, even if the average tariff rate is low. In addition, when tariffs are reduced and the cost of imports declines, demand for imports is likely to increase. At least in the short-term the volume of imports and therefore tariff revenue may, depending on elasticities of demand, increase. However, Tanzania's tax revenue as percent of GDP declined from 17.8 percent in 1979/80 to 9.8 percent in 1998/99 (Table 1). The IMF (2003) reports that policy sequencing attributes to the revenue decline. For example, tariffs were lowered too quickly before compensatory tax broadening measures and a strengthened tax administration were in place (IMF, 2003). With tariff rates declining overtime, revenues from import duties as a share of total revenue have also tended to decline, particularly between the second half of 1990s and the 2000s, but they remain important sources of revenue because they are relatively easy to collect. Table 1 indicates that revenue from import duty as a percent of total revenue declined from 15.4 percent in $1996 / 97$ to 8.4 in 2009/10 partly as a result of the reduction in trade tariffs (African Development Bank Group, 2009). Decrease in total tax revenue and import duty revenue is closely linked to an overall trend towards trade liberalization-proxied, for example, by a decline in collected tariff rates (Figure 1).

It is widely recognised that trade liberalization does not necessarily reduce revenue from trade taxes when it involves cutting tariffs that are initially set for protective reasons so as to increase trade volume by more than enough to offset the direct revenue loss from lower rates. Trade liberalization also may not reduce trade taxes when it is accompanied with reducing distorting exemptions and addressing corrupt administration. However, trade liberalization must reduce trade tax revenue because free trade ultimately means no import duty revenues. Collected tariff rates are now low in Tanzania relative to levels that are likely to be revenue maximizing. Khattry and Rao (2002) for instance, estimate the revenue maximizing tariff rate for low income countries to be in the order of 38 percent, while Ebrill et al. (1999) put it at around 24 percent. It is notable that with the collected tariff rate, around 6.2 percent between $1997 / 98$ and 2009/10, Tanzania has collected tariff rates below revenue maximizing average tariff rates set by Khattry and Rao (2002), and Ebrill et al. (1999). The collected tariff rate was around 10 percent in 1996 , whereas import duty revenue -to-GDP ratio accounted for 2.1 percent. In 2010, the collected tariff rate and import duty revenue share in GDP, respectively accounted for 8.4 and 1.4 percent, after several 
years of fluctuations. This implies that trade values are likely to prove much less responsible to further lowering of tariff rates, and therefore tax revenue from trade may fall and consequently a fall in government revenue.

Tanzania has been unable to recover import duty revenue loss from trade liberalization through strengthened domestic taxation, as a result total tax revenue as a percent of GDP has on average declined in parallel with import tax revenue. These concerns are emerging ever more clearly as potentially significant obstacles to further liberalization. However, total tax revenue-to-GDP ratio improved in recent years partly due to improvement in revenue collections through excise duty and VAT on imports. Moreover, it is expected that, the efficiency gains from trade liberalization means an increase in aggregate real income, part of which could be captured as government revenue through income tax and hence, minimizing the loss arises from tariff rate reduction. Several features however, characterize the income tax regime in Tanzania, which accounted for 28.7 percent of total tax revenue and 4.1 percent of GDP during the 1979/80-2009/10 period. First, it has been mainly limited to the formal sector and the number of individuals subject to personal income is small. Second, the effectiveness of rate progressivity is undercut by high personal exemptions and deductions that benefit those with high incomes. The problem of exemptions and deductions tends to narrow the tax base and negate effective progressivity. Thus, the decline of total tax revenue as a percent of GDP in Tanzania occurs not only as a direct consequence of declining import duty revenue-to-GDP ratio, but also as a result of declining income taxes as a percent of GDP.

Table 1. Various Tax Revenues as Percent of GDP and of Total Tax Revenue, 1979/80-2009/10

\begin{tabular}{|c|c|c|c|c|c|c|c|c|c|c|c|c|c|}
\hline \multirow{3}{*}{ Year } & \multirow{3}{*}{$\begin{array}{l}\text { Tax } \\
\text { Revenue } \\
\text { \% of GDP }\end{array}$} & \multicolumn{6}{|c|}{ Trade Taxes } & \multirow{2}{*}{\multicolumn{2}{|c|}{ Sales/VAT }} & \multirow{2}{*}{\multicolumn{2}{|c|}{ Income Tax }} & \multirow{2}{*}{\multicolumn{2}{|c|}{ Other Taxes }} \\
\hline & & \multicolumn{2}{|c|}{ Import Duty } & \multicolumn{2}{|c|}{$\begin{array}{c}\text { Sales/VAT on } \\
\text { Import }\end{array}$} & \multicolumn{2}{|c|}{$\begin{array}{c}\text { Excise on } \\
\text { Import }\end{array}$} & & & & & & \\
\hline & & $\begin{array}{l}\% \text { of } \\
\text { GDP }\end{array}$ & $\begin{array}{l}\text { \% of } \\
\text { Total Tax }\end{array}$ & $\begin{array}{l}\% \text { of } \\
\text { GDP }\end{array}$ & $\begin{array}{l}\% \text { of } \\
\text { Total } \\
\text { Tax } \\
\end{array}$ & $\begin{array}{l}\% \text { of } \\
\text { GDP }\end{array}$ & $\begin{array}{l}\% \text { of } \\
\text { Total } \\
\text { Tax } \\
\end{array}$ & $\begin{array}{l}\% \text { oof } \\
\text { GDP }\end{array}$ & $\begin{array}{l}\text { \%oof } \\
\text { Total } \\
\text { Tax } \\
\end{array}$ & $\begin{array}{l}\% \text { of } \\
\text { GDP }\end{array}$ & $\begin{array}{l}\text { \% of } \\
\text { Total } \\
\text { Tax } \\
\end{array}$ & $\begin{array}{l}\% \text { oof } \\
\text { GDP }\end{array}$ & $\begin{array}{l}\text { \% of } \\
\text { Total } \\
\text { Tax } \\
\end{array}$ \\
\hline $1979 / 80$ & 17.8 & 2.1 & 11.9 & 0.5 & 3.0 & 0.3 & 1.8 & 7.7 & 43.2 & 6.3 & 35.3 & 1.4 & 7.8 \\
\hline $1980 / 81$ & 18.2 & 1.5 & 8.1 & 0.9 & 5.0 & 0.4 & 2.0 & 9.7 & 53.3 & 6.1 & 33.5 & 0.6 & 3.1 \\
\hline $1981 / 82$ & 16.4 & 1.2 & 7.3 & 1.2 & 7.0 & 0.2 & 1.1 & 9.1 & 55.3 & 5.8 & 35.0 & 0.2 & 1.3 \\
\hline $1982 / 83$ & 15.1 & 1.0 & 6.5 & 1.2 & 7.7 & 0.5 & 3.3 & 8.2 & 54.2 & 5.1 & 33.8 & 0.3 & 2.2 \\
\hline $1983 / 84$ & 18.1 & 1.3 & 7.0 & 2.0 & 10.9 & 0.9 & 5.0 & 10.4 & 57.7 & 5.4 & 29.8 & 0.1 & 0.5 \\
\hline $1984 / 85$ & 21.6 & 1.9 & 8.8 & 1.1 & 5.0 & 1.4 & 6.6 & 12.1 & 55.8 & 6.0 & 27.8 & 0.2 & 1.1 \\
\hline $1985 / 86$ & 19.4 & 1.5 & 7.7 & 0.7 & 3.8 & 0.7 & 3.8 & 9.5 & 48.8 & 6.4 & 32.9 & 1.3 & 6.8 \\
\hline $1986 / 87$ & 18.5 & 2.5 & 13.8 & 2.3 & 12.4 & 0.4 & 2.0 & 10.8 & 58.7 & 4.6 & 24.9 & 0.1 & 0.6 \\
\hline $1987 / 88$ & 12.9 & 1.8 & 13.7 & 1.1 & 8.4 & 0.5 & 3.7 & 6.9 & 53.4 & 2.9 & 22.9 & 0.8 & 6.5 \\
\hline $1988 / 89$ & 12.5 & 1.6 & 13.0 & 1.5 & 12.0 & 0.5 & 4.2 & 6.6 & 52.7 & 3.0 & 23.9 & 0.8 & 6.2 \\
\hline $1989 / 90$ & 12.9 & 1.9 & 14.8 & 1.3 & 10.5 & 0.5 & 4.0 & 4.5 & 35.1 & 3.1 & 23.9 & 2.9 & 22.2 \\
\hline 1990/91 & 14.2 & 1.4 & 9.5 & 1.2 & 8.1 & 0.7 & 5.1 & 2.4 & 17.1 & 3.0 & 23.5 & 7.2 & 44.8 \\
\hline $1991 / 92$ & 14.1 & 1.5 & 10.4 & 1.2 & 8.3 & 0.8 & 5.4 & 4.1 & 29.3 & 3.0 & 21.3 & 4.8 & 33.7 \\
\hline $1992 / 93$ & 10.7 & 1.5 & 14.0 & 1.0 & 9.4 & 0.2 & 1.9 & 3.0 & 28.0 & 3.4 & 31.8 & 2.6 & 24.3 \\
\hline $1993 / 94$ & 12.8 & 1.4 & 11.0 & 1.0 & 7.8 & 0.1 & 0.8 & 3.7 & 28.7 & 3.2 & 25.1 & 4.4 & 34.5 \\
\hline $1994 / 95$ & 13.0 & 1.8 & 13.8 & 1.2 & 9.2 & 0.4 & 3.1 & 3.2 & 24.2 & 3.4 & 26.1 & 4.3 & 32.9 \\
\hline $1995 / 96$ & 12.7 & 1.9 & 15.0 & 1.2 & 9.4 & 0.7 & 5.5 & 3.1 & 24.7 & 3.4 & 26.8 & 3.6 & 28.1 \\
\hline $1996 / 97$ & 13.4 & 2.1 & 15.4 & 1.5 & 10.8 & 0.8 & 5.9 & 3.2 & 24.1 & 3.3 & 24.8 & 4.0 & 29.9 \\
\hline $1997 / 98$ & 11.9 & 1.7 & 14.6 & 1.6 & 13.6 & 0.5 & 4.0 & 2.9 & 24.6 & 3.2 & 26.7 & 3.6 & 30.1 \\
\hline 1998/99 & 9.8 & 1.4 & 14.2 & 1.7 & 17.0 & 0.4 & 4.2 & 3.5 & 35.6 & 2.5 & 26.0 & 2.0 & 20.1 \\
\hline $1999 / 00$ & 9.8 & 1.2 & 12.4 & 1.5 & 15.4 & 0.3 & 3.1 & 3.1 & 32.0 & 3.9 & 29.9 & 2.2 & 22.6 \\
\hline $2000 / 01$ & 10.6 & 1.2 & 11.2 & 2.2 & 21.1 & 1.1 & 10.0 & 4.0 & 37.4 & 2.7 & 25.1 & 1.7 & 16.3 \\
\hline $2001 / 02$ & 10.7 & 1.0 & 9.2 & 2.3 & 21.4 & 1.2 & 10.7 & 4.1 & 38.4 & 2.8 & 26.1 & 1.7 & 15.5 \\
\hline $2002 / 03$ & 11.0 & 1.0 & 9.4 & 2.4 & 21.9 & 1.0 & 8.9 & 4.3 & 39.5 & 3.0 & 27.3 & 1.6 & 14.9 \\
\hline $2003 / 04$ & 11.5 & 1.1 & 9.5 & 2.5 & 21.1 & 1.0 & 8.7 & 4.4 & 38.6 & 3.3 & 29.2 & 1.6 & 13.9 \\
\hline $2004 / 05$ & 12.1 & 0.8 & 6.3 & 3.1 & 26.0 & 0.9 & 7.6 & 5.2 & 43.1 & 3.7 & 30.3 & 1.5 & 12.7 \\
\hline $2005 / 06$ & 12.7 & 1.1 & 8.8 & 3.1 & 24.9 & 0.8 & 6.3 & 5.2 & 41.4 & 4.0 & 31.6 & 1.5 & 12.0 \\
\hline $2006 / 07$ & 14.6 & 1.4 & 9.4 & 2.6 & 17.7 & 1.7 & 11.9 & 4.9 & 33.8 & 4.8 & 32.6 & 1.8 & 12,4 \\
\hline $2007 / 08$ & 16.5 & 1.5 & 8.8 & 2.6 & 15.9 & 2.1 & 12.7 & 5.3 & 31.7 & 5.3 & 31.9 & 2.5 & 14.9 \\
\hline $2008 / 09$ & 16.8 & 1.5 & 9.0 & 2.6 & 15.4 & 1.9 & 11.4 & 5.4 & 32.1 & 5.5 & 32.4 & 2.5 & 15.1 \\
\hline $2009 / 10$ & 16.3 & 1.4 & 8.4 & 2.7 & 16.6 & 1.9 & 11.7 & 5.3 & 32.5 & 5.3 & 32.8 & 2.4 & 14.6 \\
\hline
\end{tabular}

Notes: Sales/VAT includes sales/VAT on domestic and import consumption; Income Taxes include PAYE and corporate tax; Other taxes include domestic excise duty, other income taxes, other import charges, and other domestic charges

Source: Computed using data from Bank of Tanzania: A Review of the Role and Functions of the Bank of Tanzania (1961-2011 and Tanzania Revenue Authority: National Tax Statistics, 2011. 


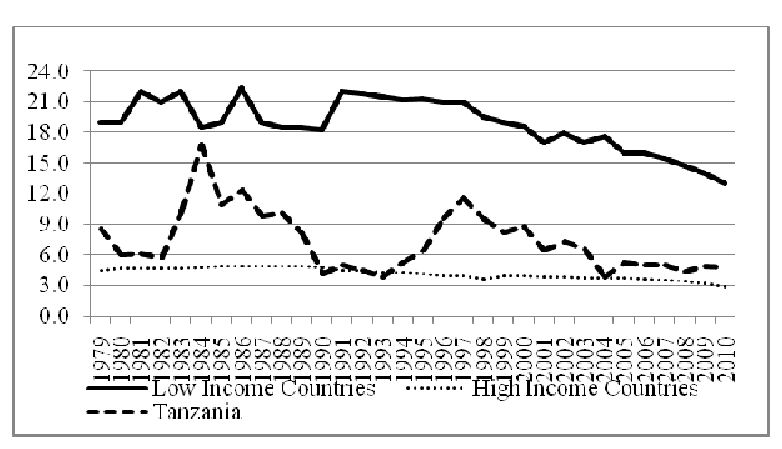

Figure 1. High Income and Low Income Countries: Collected Tariff Rates, 1979-2010

Source: IMF TPIDB; Bank of Tanzania A Review of the Role and Functions of the Bank of Tanzania, 1961-2011; and Tanzania Revenue Authority: National Tax Statistics, 2011

\section{Literature Review}

\subsection{Theoretical Rationale for Trade Liberalization and Tax Revenue}

Considerable evidence has accumulated overtime that trade liberalization is linked to higher rates of economic growth, which is its main objective (Escolano, 1995). Trade liberalization stimulates a better reallocation of resources in terms of comparative advantage and can also stimulate long-run growth through the accumulation of capital and technology for developing countries. The link between economic openness and growth is quite strong; for example, while developing countries in Latin America and sub-Saharan Africa that followed import substitution industrialization strategies experienced relatively lower growth rates, East Asian countries, that employed export-promotion policies, consistently outperformed other countries. This enhanced growth leads to expansion of tax bases, with a concomitant expansion of revenue potential. Overtime the influence of economic growth on revenue may dominate the influence of shorter-term changes in the trade regime. A higher per-capita income reflecting a higher level of development is held to indicate a higher capacity to pay taxes as well as a greater capacity to levy and collect them (Chelliah, 1971).

Although, trade liberalization is expected to enhance economic efficiency and growth, it is widely recognized that the effect of cutting tariff is ambiguous. On one hand, lower tariffs imply lower tax rates and hence smaller revenues. On the other hand, the volume of imports tends to expand when tariffs are reduced and hence the tax base will follow suit. The normal argument is that rationalizing the tariff system reduces opportunity and incentive for evasion so compliance increases, and so revenue may increase. Higher tariffs create an incentive for importers to evade tariff or seek exemptions (Pritchett and Sethi, 1994). In turn, tax evasion affects the productivity of the tax system leading to a less than proportionate increase in tariff revenue. Which of the two effects is larger will depend on the demand elasticity of imports. If the elasticity is sufficiently high and tax compliance is high, then revenue should increase.

Trade liberalization is often accompanied by a devaluation of nominal and real exchange rates. This raises the domestic value of imports, with a positive effect on trade tax revenues. But the domestic cost of government spending programmes will increase. Consumption will switch from tradable to non-tradable goods, trade tax revenue will therefore decline and those from domestic indirect taxation will increase. The overall effect of devaluation is therefore ambiguous. Long-run effects may be driven by enhanced growth performance as a result of trade liberalization. If growth increases then increased income levels will translate into a large base for domestic direct taxation (UNECA, 2004). The trade liberalization measures and their implications on the revenue can be positive, negative and neutral depending on the nature of restrictions and the characteristics of a particular country (Ebrill et al., 1999). When the trade regime is very restrictive because of high tariff rates, trade volumes are likely to be reduced. Reducing restrictions will result in a strong increase in trade volumes. But when the trade regime is faintly already liberalized, further reduction in restrictions will not cause a sufficiently large increase in trade volumes to offset the lower tariffs. This effect is illustrated by a "Laffer" curve, tracking the relationship between revenues and the trade restrictions (average "realized" tariffs), being defined as import duty revenue divided by import value.

\subsection{Empirical Evidence on Trade Liberalization and Tax Revenue}

The relationship between trade liberalization and tax revenue has been debated in economic literature, especially in the last two decades. In general, the revenue implications of trade liberalization are uncertain. Agbeyegbe et al. (2003), using a panel of 22 countries in sub-Saharan Africa, over the 1980-1996 period, report that the revenue impact of trade liberalization is limited. Overall, revenue tends to be least affected if the initial position of the trade regime is highly restrictive and if liberalization is accompanied by reforms in customs and tax administration with the aim to broaden tax base. Postulating a first-order dynamic panel model with a number of explanatory variables, they find evidence that trade liberalization is linked to higher tax revenue and trade tax revenue. They also find that the exchange rate is not generally strongly linked to revenues.

By contrast Khattry and Rao (2002) find that the impact of trade liberalization on revenue is significantly negative. For the aggregate sample of 80 countries both developed and developing countries over the $1978-99$ period, and applying a number of regressors on tax revenue regression and trade tax revenue regression, Khattry and Rao (2002) find that domestic indirect tax revenue-to-GDP and the trade-to-GDP ratios are significantly and negatively correlated indicating that customs duties on tradables are particularly replaced by 
domestic indirect taxes on tradables. They also find that there is strong evidence that structural factors play a significant role in determining the trade tax revenue-to-GDP ratio across countries. For example, tax revenue-to-GDP ratio varies positively with the level of development while the share of trade taxes in GDP varies inversely with the level of development. Moreover, reduced protection adversely affects overall tax revenue and trade revenue receipts. In addition, low income country group face declining tax revenue-to-GDP ratio in the awake of trade reform, which is associated with substantial increase in the debt-to-GDP ratio. They conclude that trade liberalization in developing countries results in revenue losses due to inability to compensate for forgone tariff revenue by raising higher revenue from domestic sources.

Similarly, the Economic Commission for Africa (UNECA, 2004) study for fiscal implication of trade liberalization on African countries reveals that trade liberalization is a potential source of fiscal instability for Africa countries because of their high dependence on international trade tax. UNECA (2004) applies the Generalized Method of Moments of Arellano and Bond (1991) to estimate both tax revenue and trade tax revenue regressions for all African countries except Democratic Republic of Congo, Eritrea, Liberia, Libya, and Somalia over the 1980-2002 period. The main finding of that study is that the decrease in trade tax revenue can be matched by an increase in revenue from domestic tax, and in particular most countries increased reliance on VAT. The study concludes that sound macroeconomic environment is critical to preventing fiscal distress during trade liberalization. By achieving a sound macroeconomic stance e.g. low and predictable inflation, high GDP growth etc. countries can progress toward fiscal stability during liberalization period. Moreover, effective institutional reform is likely to help fiscal consolidation.

In a review of African countries experience of fiscal impact of trade liberalization, Fukasaku (2003) finds that the overall impact of trade liberalization in sub-Saharan Africa is ambiguous and depends on a multiplicity of facts such as the nature and sequencing of reforms. Examining a database of 22 African countries, he finds that trade liberalization has contributed to declines in the ratio of trade-to-total government revenue of more than 20 percent in Mauritius, more than 10 percent in Côte d'Ivoire and Senegal, and more than 5 percent in Cameroon, Tunisia, and Mozambique. In most countries, domestic resources mobilization was somewhat weaker. Similarly, Ebrill et al. (1999) find that many developing countries have implemented trade reform while avoiding significant revenue loss. In some cases revenue increases because a country's reduction of tariff and non-tariff barriers generates more imports. Mexico and Chile witnessed such revenue increases in short term, when they implemented liberalization programs in the 1980s (WTO, 2003). Ebrill et al. (1999) study concludes that trade liberalization could be tailored to avoid adverse consequences. For example, revenue objectives can be met when reductions in tariffs are accompanied by improved customs administration and reduction in exemptions, non-tariff barriers, and regulations. Nevertheless, in the long-term, trade liberalization inevitably reduces the total share of revenue derived from trade taxes. To ensure that revenue is maintained, domestic tax reforms must accompany trade liberalization. But such reforms take time to develop and implement. Eventually, however, trade liberalization must reduce trade tax revenue simply because free trade ultimately means no trade taxes and many countries are now likely to be in this situation. Some countries have resorted to other sources of government revenue, such as income, excise, or value added taxes (Ebrill et al., 1999).

Paudel (2006) examines the revenue implications of World Trade Organization (WTO) regime and alternative measures for revenue mobilization in Nepal for the1975-2005 period. He argues that about 25 percent of the import duty is lost with the fulfillment of WTO commitment Paudel (2006) estimates the time series trade regression equation applying variables such as import duty as percent of GDP, import trade as percent of GDP, real effective exchange rate, un-weighted overall average tariff rate, and dummy variable as a proxy for trade liberalization. He observes that import-to-GDP ratio increased after the trade liberalization whereas the average (collected) tariff rate declined in the same period indicating that the increase in import-to-GDP ratio may not be sufficient enough to offset the loss of revenue due mainly to declining trade taxes in the short-run. He concludes that the higher import-to-GDP ratio appears to compensate for the reduction in trade revenue arising from the trade liberalization in a long-run.

Matlanyane and Harmse (2001) apply the ordinary least square on annual time series data from 1974-2000 to estimate the productivity of trade tax revenue and to establish the effect of trade liberalization on tariff revenue in South Africa. The trade tax equation is estimated in linear logarithmic form where customs revenue is used as proxy for international trade tax revenue and dummy variable for liberalization. Their main finding is that customs revenue is highly productive. In addition, trade liberalization has a significant influence on customs revenue and that an increase in import tax rate leads to a reduction in trade tax revenue. On the other hand, Matlanyane and Harmse (2001) find that supportive macroeconomic policies are a prerequisite for successful trade liberalization.

In different studies, Blejer and Cheasty (1990) and Tanzi (1989) conclude that the net impact of trade reform on revenue is an empirical matter. Rodrik (2001) argues that the benefits of trade reform have been oversold and that economic policy should focus on growth and not trade. Rodrik (2001) critizes the standard trade theory and the argument by Edward (1993) that, suggest that there is a strong empirical correlation between an open trade policy and economic growth since trade liberalization has a positive effect on exports growth. However, Rodrik (1995) shows that there is a robust negative relationship between per capita income and the share of trade taxes in total tax 
revenue: an increase in per capita income of US\$1,000 is associated with a reduction by 3.7 percent points in the share of trade tax revenue. The usual explanation is that in the countries with poor administrative capabilities trade taxes may be the easiest way for governments to raise revenue (Kubota, 2000; and McLaren, 1998).

\subsection{Knowledge Gaps}

It is noted that the empirical studies have not resolved the debate over the impact of trade liberalization on tax revenue. The empirical findings have been mixed because of their sensitivity to set of countries and the period of analysis. While trade liberalization can help accelerate integration in the world economy and strengthen an effective growth strategy, it cannot ensure its success. Other elements that address binding constraints to growth such as macroeconomic management, trade related infrastructure and institutions are needed. Unlike South-East Asian countries, which are more competitive and integrated into the global economy, moving from export of raw materials to a more dynamic integration focused on high technology product, Tanzania, and other sub-Saharan Africa countries have great difficulty in dealing with their increasing impact of trade liberalization on tax revenues. For example, the economy of Tanzania is mainly characterized by low-income and based on subsistence agriculture, which is difficult to tax. Moreover, budgetary income is closely tied to international trade revenue. From this viewpoint, trade liberalization could create a considerable gap in revenue and might lead to a worsening of major macroeconomic imbalances. Most studies on the impact of trade liberalization on tax revenue, however, are based on a large sample of developing countries, few focuses on specific emerging economy. To fill this gap this study examines the revenue implications of trade liberalization in Tanzania. This contribution is part of debate and, on the basis of less developed country seeks to add some ideas to the relationship between trade liberalization and tax revenue.

\section{Methodology and Data Description}

\subsection{The Theoretical Model}

The share of international trade in the economy is a measure of openness, which may also be a proxy for trade liberalization. Certain factors of international trade make it more suitable to taxation than domestic activities. In Tanzania, the international trade sector is typically the most monetized sector of the economy and has gained increasing importance in recent years. A positive correlation would be expected between the import shares in the economy (IMPORT) and the import duty revenue-to-GDP ratio (IDR) as administrative costs of the tax system to this sector should be lower than other sectors. The relationship between imports, trade liberalization, and import duty, however is not direct. A country that taxes imported goods with very high tariffs discourage imports, tariffs may be above the level that would maximize revenue from import duties. In this case some reduction of import duties, by encouraging more imports, would increase and not reduce import duty taxes. For some range of the rate of import duty, a lowering of the rate will increase imports by so much as to more than compensate for the reduction in the tax rate. In this range, imports are elastic with respect to the import duty. There is a point at which the level of import duties is such as to maximize revenue from trade taxes. Below this point, however, the reduction in import duties would reduce the revenue from import taxes.

Apart from the share of import in GDP, there are other several determinants of import duty revenue in Tanzania and other low income countries; though any generalization is difficult given the differences in the political and economic structure across the countries. The economy of Tanzania is characterized by low per capita GDP $(p c G D P)$. Per capita GDP is considered to capture the level of development. Higher income countries tend to have a more monetized economy and better tax administration but less rely on trade taxes, the coefficient of the per capita GDP is, therefore, expected to be negative. This is considered to reflect features of Tanzania economy with difficulties in administering an effective domestic tax system and relatively small share of formal sector in the economy. Farhadian-Lorie and Katz (1989) note that tariff taxes are historically been a major source of government revenue during the early stages of economic development because they are easier to collect than domestic income or consumption taxes, owing to the rudimentary status of tax administration, as well as the limited availability of tax base. During the later stages of development, however, collection costs are expected to fall, dependence on tariff taxes to decline, and dependence on indirect taxes to rise.

The effect of macroeconomic policy on import duty revenue is also captured in the real exchange rate (RER). Real exchange rate index is defined such that an increase indicates a real depreciation and its coefficient could in general be expected to be positive, since a real depreciation implies higher nominal value of imports and hence increased import duty revenue. Nevertheless an overvaluation of the real exchange rate-typically brought about by expansionary financial policies-would be expected to adversely affect overall economic activities, and thus to lower tax revenue.

The general advice given by international institutions such as IMF and the World Bank to developing countries over past few decades has been to replace trade taxes with domestic consumption taxes (CTAX), particularly, VAT, and income taxes (DTAX), particularly corporate income tax. However, some recent literature challenges this conventional view, arguing that the relatively large informal sector in developing countries may justify a different tax policy design. For example the income tax base in developing countries such as Tanzania is mostly comprised of wages of public sector employees because most other taxpayers are self-employed or small businesses who evade pay of all, or most of income tax. In addition, taxation of 
personal capital income is easily evaded (IMF, 2005). Similarly, the relevant data shows that the performance of VAT was quite satisfactory in the initial years but subsequently VAT collection has remained stagnant at a certain level. As a result, VAT is unable to meet the objectives for which it was introduced. The reasons behind this performance are many, such as a relatively small number of VAT tax-payers, exemption of agricultural production and other products, and a weak monitoring system. Therefore, there is no clear evidence whether Tanzania is able to replace revenue loss from international trade through domestic taxes.

\subsection{Conceptual Framework}

Since trade liberalization entails reducing tariff rates, then, the revenue implications would depend on the elasticities of import demand and supply with respect to the tax rates. A sufficiently elastic response would imply that revenue would increase as a result a decrease in tariff rates.

The restrictiveness of the trade regime is proxied by the collected tariff rate. The relationship between the collected rate of trade taxation and import duty revenue is assumed to be nonlinear as prohibitively high rates of the trade taxation may lead to declining import duty revenue. A quadratic form is therefore applied to estimate the effects of trade liberalization on import duty revenue. The overall marginal effect of tariff rate on import duty revenue is then $\left(\gamma_{1}+2 \gamma_{2} C T R\right)$ and hence depends on CTR (see Ebrill et al., 999). The revenue-maximizing rate of trade taxation is obtained by solving for CTR in the following equation: $\left(\gamma_{1}+2 \gamma_{2} C T R\right)=0$, that is $C T R=-\gamma_{1} / 2 \gamma_{2}$ (see Khatty and Rao, 2002).

Many studies on the impact of trade liberalization on revenue emphasize on policy decisions that tend to replace import duty revenue with domestically based taxes such as domestic consumption taxes, both excise on goods and VAT to offset any revenue loss from trade liberalization. Similarly, efficiency gains from trade liberalization means an increase in aggregate real incomes part of which could be captured as government revenue through the income tax. Import duty revenue model therefore, predicts that Tanzania can compensate revenue loss from trade liberalization by raising revenue on domestic consumption of goods and services and income taxes. Thus, the model is specified as

$$
\begin{aligned}
I D R_{t}= & \gamma_{0}+\gamma_{1} C T R_{t}+\gamma_{2}(C T R)^{2}+\gamma_{3} \log \left(p c G D P_{t}\right)+\gamma_{4} R E R_{t} \\
& +\gamma_{5} \text { IMPORT }_{t}+\gamma_{6} C T A X_{t}+\gamma_{7} D T A X_{t}+\varepsilon_{t}
\end{aligned}
$$

\subsection{Definitions and Expected Signs on Variable Parameters}

Table 2 presents the definitions and expected signs of variables used in the tax ratio equation. For estimation, the collected tariff rate, measured by the ratio of import duties to the value of imports, is considered as a proxy of degree of liberalization. With this measure, a decline in the index is considered to indicate greater trade liberalization. ${ }^{1}$ The measure is based on how much tariff revenue is actually collected; it may differ from official tariffs because of imperfect collection and measurement errors. Data are available to construct the index for fairly long time periods for Tanzania. The appropriateness of this measure is also discussed in Ebrill et al. (1999).

The per capita GDP variable is entered in logarithm, while the remaining variables are entered linearly because the tax revenue function is assumed to be nonlinear in the scale of the economy (as measured by per capita GDP) (see Kattry and Rao, 2002; Ebrill et al.,1999). The study uses the ratio of GDP. GDP includes income earned locally that accumulates to non-residents and excludes income received from abroad by residents, since local income accruing to non-residents typically is taxed while remittances from abroad typically are not.

\begin{tabular}{|c|c|c|c|}
\hline Variable & Abbrev. & Definition & $\begin{array}{l}\text { Expected } \\
\text { Sign } \\
\end{array}$ \\
\hline $\begin{array}{l}\text { Import Duty } \\
\text { Revenue }\end{array}$ & $I D R$ & $\begin{array}{l}\text { Import Duty Revenue as } \\
\text { Percent of GDP }\end{array}$ & \\
\hline $\begin{array}{l}\text { Collected } \\
\text { Tariff Rate }\end{array}$ & CTR & $\begin{array}{l}\text { Import Duty Revenue as } \\
\text { Percent of Import Value }\end{array}$ & $\gamma_{1}>0$ \\
\hline $\begin{array}{l}\text { Collected } \\
\text { Tariff Rate } \\
\text { Square }\end{array}$ & $(C T R)^{2}$ & $\begin{array}{l}\text { Collected Tariff Rate } \\
\text { Square (Included to } \\
\text { Capture the Laffer Curve } \\
\text { Effect) }\end{array}$ & $\gamma_{2}<0$ \\
\hline $\begin{array}{l}\text { Per Capita } \\
\text { GDP }\end{array}$ & $p c G D P$ & $\begin{array}{l}\text { Log of Real Per Capita } \\
\text { GDP }\end{array}$ & $\gamma_{3}<0$ \\
\hline $\begin{array}{l}\text { Real } \\
\text { Exchange } \\
\text { Rate }\end{array}$ & $R E R$ & $\begin{array}{l}\text { Calculated from } \\
\text { Nominal Exchange Rate } \\
\text { and CPI }\end{array}$ & $\gamma_{4}>0$ \\
\hline $\begin{array}{l}\text { Value of } \\
\text { Import }\end{array}$ & IMPORT & $\begin{array}{l}\text { Import Value (Percent of } \\
\text { GDP) }\end{array}$ & $\gamma_{5}>0$ \\
\hline $\begin{array}{l}\text { Domestic } \\
\text { Consumption } \\
\text { Taxes }\end{array}$ & CTAX & $\begin{array}{l}\text { Indirect (Consumption) } \\
\text { Taxes (Percent of GDP) }\end{array}$ & $\begin{array}{l}\gamma_{6}<0 \\
\text { or } \gamma_{6}>0\end{array}$ \\
\hline $\begin{array}{l}\text { Domestic } \\
\text { Income Taxes }\end{array}$ & DTAX & $\begin{array}{l}\text { Direct Taxes (Percent of } \\
\text { GDP) }\end{array}$ & $\begin{array}{l}\gamma_{7}<0 \\
\text { or } \gamma_{7}>0\end{array}$ \\
\hline
\end{tabular}

Table 2. Descriptions of Variables

Source: Constructed from Literature Review

\subsection{Data Sources and Time Series Characteristics of Data}

\subsubsection{Data Sources}

Various categories of tax revenues and data on GDP are obtained from Bank of Tanzania: A Review of the Role and Functions of the Bank of Tanzania (1961-2011), and Tanzania Revenue Authority: National Tax Statistics, 2011. Data on series on macroeconomic variables such as real exchange rate, and trade balance (imports and exports) are

\footnotetext{
${ }^{1}$ The collected import tariff rate (tariff revenues divided by import value) is frequently used as a proxy for the level of tariff protection, but changes in this rate do not capture other important elements of trade liberalization such as lowering non-tariff barriers (NTBs). For further discussion, see Ebrill, Stotsky and Gropp, 1999).
} 
obtained from Bank of Tanzania, the International Monetary Fund (IMF): International Financial Statistics (IFS), World Trade Organization (WTO), United Nations Conference on Trade and Development (UNCTAD): Handbook of Statistics, 2006/07 and 2009/10, and the Economic Research Services (ERS)/ USDA: International Macroeconomic Data set.

\subsubsection{Time Series Characteristics of the Data}

It is widely accepted that regression of non stationary time series may indicate significant relationship even if the actual relationship is spurious. For empirical analysis therefore, it is important to take into account the underlying properties of the processes that generate the time series variables, more specifically, whether the variables under consideration are stationary and have long-run relationships. In this connection, tests to detect non stationarity and determine the order of integration of the variables in the model have to be conducted.

\subsubsection{Stationarity and Unit Root Test}

Economic variables that are non-stationary are characterized by a change in variance that becomes infinite overtime. In addition, the series wanders without reverting to the fixed mean. These characteristics result in spurious relations between variables in econometric analysis. The use of time series variables in estimating econometric models requires that a stochastic process generating the data series be stationary. The stochastic process is stationary if all the variables generated have constant mean and constant variance over the time.

There are several methods that have been devised to test for unit root in time series variables. These methods include Q-statistics, Ljung-Box statistics, weighted symmetric test, Phillips-Perron (PP), Dickey-Fuller (DF) and Augmented Dickey Fuller (ADF) tests. ${ }^{2}$ The Dickey Fuller (DF), Augmented Dickey Fuller (ADF) and the Phillips-Perron (PP) unit root tests are the commonly used methods to test the stationarity of the time series variables. In this study ADF and PP tests are used. The idea behind the ADF and PP unit root tests is that, the ADF and PP tests use different methods to control for higher-order serial correlation in the series and have been widely used successfully in other studies. The ADF test makes a parametric correlation for higher-order correlation by assuming that the series, say IDR follows autoregressive process and adjusting the test methodology. Moreover, the ADF approach controls for higher-order correlation by adding lagged difference terms of the dependent variable (IDR) to the right-hand side of the

\footnotetext{
${ }^{2}$ The ADF test is virtually the same as the DF test, except the lag length has to be long in order to reflect the additional dynamics that cannot be captured by the DF test and to ensure that the error term is white noise. The ADF is presented as $\Delta Y_{t}=\alpha+\lambda t+\delta y_{t-1}+\sum_{i=1}^{i} \phi_{i} \Delta y_{t-i}+\varepsilon_{t}$, where the lag length $i$ is set to ensure that any autocorrelation in $\Delta Y_{t}$ is absorbed. This augmented specification is then used to test the hypothesis that: $H_{0}: \delta=0, H_{1}: \delta\langle 0$.
}

regression. Phillips-Perron test is a nonparametric method of controlling for higher-order serial correlation in a series. The PP makes a correlation to the t-statistics of IDR coefficient from the $A R(1)$ regression to account for the serial correlation in error term $(\varepsilon)$. The correlation is nonparametric since we use an estimate of the spectrum of $\varepsilon$ at frequency zero that is robust to heteroskedasticity and autocorrelation of unknown form. There is evidence that the Phillips-Perron test has more power than the augmented Dickey-Fuller test (Davidson and MacKinnon, 1993). If the variables are found to be $I(1)$ stationary, the next step is to test whether they are cointegrated using the Engle Granger two step procedure, as discussed in the next sub section.

\subsubsection{Cointegration Analysis and Error Correction Modelling}

Economic theory is mostly interested in equilibrium conditions and has little to say about the nature of economic configurations in disequilibrium. However, the data does not confirm that equilibrium relationships between economic variables hold at all times. To overcome this difficulty, economists make a distinction between the short-run and the long-run. The appeal of cointegration is that it provides a formal framework for testing long-run models from actual time-series data. The cointegration analysis allows non stationary data to be used so that spurious regression results are avoided. It also gives the chance to test the validity of an economic theory. If a postulated economic relationship exists, then the variables under consideration should be cointegrated. Testing for cointegration is, thus, a test for the existence of the equilibrium relationship postulated.

Granger and Engle (1987) two-step estimation procedure and the Johansen (1988) procedure are two procedures that are popularly used to identify and estimate the cointegrating vectors and the short run adjustment parameters. The former procedure involves normalizing the cointerating vector on one of the variables, which makes the assumption that the corresponding element of the cointegrating vector is non-zero. ${ }^{3}$ The Johansen procedure is a multivariate approach, the estimation of which would consume a lot of degree of freedom. In this study the Engle-Granger two-step procedure is performed to test for cointegration between variables in a single equation. The Engle-Granger type of static long-run regression has become a widely applied method since it was introduced by Engle and Granger (1987)

\footnotetext{
${ }^{3}$ Formally, Granger (1983) and Engle and Granger (1987) define that an economic time series is said to be integrated of order $d$, or $I(d)$, if it requires to be differenced $d$ times to achieve stationarity. If we have an $[n \times 1]$ vector of variables $X$, which $I(d)$, the series in $X$ are said to be cointegrated if there exists a combination $\beta^{\prime} X_{t}=\varepsilon_{t}$ such that $\varepsilon_{t}$ is $I(d-b)$ and $\beta$ is known as the cointegrating vector. The statistical concept of cointegration has a natural counterpart in economic theory. The basic idea is that the existence of cointegration between a set of economic variables implies that the variables move together in the long run, or in other words are in long run equilibrium. In testing for cointegration of economic time series, one is also testing for presence (or absence) of a long run relationship between them.
} 
Some suggest that the estimates of the Engle-Granger type static long-run ordinary-least-squares (OLS) regression parameters are both consistent and highly efficient (Stock, 1987).

\section{Empirical Results and Discussion}

\subsection{Unit Root Test}

Test for stationarity of variables before their linear combination was conducted using both Augmented Dickey-Fuller (ADF) and Phillips-Perron tests. Selection of the numbers of lags was made using t-statistics. The variables were tested for unit root using 1 lag. This was done by including only a constant and also by including a constant and trend. Constant and trend option was selected because it is a general case. The whole process was done in levels, first difference, and second difference. The results for unit root test are presented in Table 3.

The results in Table 3 indicate that import duty revenue (IDR), collected tariff rate (CTR), domestic (consumption) indirect tax revenue (CTAX), income tax revenue (DTAX) and import value (IMPORT) are integrated of order one I(1), whereas per capita GDP ( $p c G D P$ ) and real exchange rate $(R E R)$ are integrated of order two $\mathrm{I}(2)$, this suggests that further estimation would be carried while in first difference and second difference respectively in order to avoid spurious correlation.

Table 3. Unit Root Test Results

\begin{tabular}{|c|c|c|c|c|c|c|c|}
\hline \multirow{4}{*}{ Variable } & \multicolumn{6}{|c|}{ Test Statistic } & \multirow{4}{*}{$\mathrm{I}(\mathrm{d})$} \\
\hline & \multicolumn{3}{|l|}{ ADF-test } & \multicolumn{3}{|l|}{ PP-test } & \\
\hline & \multirow{2}{*}{$\begin{array}{l}\text { ADF } \\
\text { t-value }\end{array}$} & \multicolumn{2}{|c|}{ Test Critical Values } & \multirow{2}{*}{$\begin{array}{l}P P \\
\text { t-value }\end{array}$} & \multicolumn{2}{|c|}{ Test Critical Values I(d) } & \\
\hline & & $1 \%$ Level & $5 \%$ Level & & $1 \%$ Level & $5 \%$ Level & \\
\hline$I D R$ & $-4.31 * *$ & -4.30 & -3.51 & $-7.18 * *$ & -4.29 & -3.56 & $\mathrm{I}(1)$ \\
\hline CTR & $-3.88^{*}$ & -4.30 & -3.57 & $-5.86^{* *}$ & -4.29 & -3.56 & $\mathrm{I}(1)$ \\
\hline$P c G D P$ & $-4.37 * *$ & -4.32 & -3.57 & $-8.30^{*}$ & -4.30 & -3.57 & $\mathrm{I}(2)$ \\
\hline$R E R$ & $-5.63 * *$ & -4.32 & -3.57 & $-6.47^{* *}$ & -4.30 & -3.57 & $\mathrm{I}(2)$ \\
\hline IMPORT & $-3.14 *$ & -3.67 & -2.96 & $-4.29 * *$ & -3.56 & -3.21 & $\mathrm{I}(1)$ \\
\hline CTAX & $-4.21 * *$ & -4.30 & -3.57 & $-5.50 * *$ & -4.29 & -3.56 & $\mathrm{I}(1)$ \\
\hline DTAX & $-4.91 * *$ & -4.30 & -3.57 & $-4.37 * *$ & -4.29 & -3.56 & $\mathrm{I}(1)$ \\
\hline
\end{tabular}

Notes :(1) I(d)= Order of Integration (2)*(**) denote rejection of the null hypothesis at $5 \%$ \& $1 \%$ critical values respectively (3) Included in the test equation: (i) trend and intercept (ii) lagged difference (1).

\subsection{Cointegration Analysis}

According to Thomas (1993), if an equilibrium relationship exists, then the disequilibrium error should fluctuate about zero (Figure 2). This implies that stationarity of the error term must be obtained at its initial level. A more useful way of cointegration is by using a single equation error correction model (SEECM), in which a static regression model is estimated Such a method allows for the possibility of including more than one independent variables in the static regression (Charemza and Deadman 1992). Therefore, the Engle-Granger (two-step) single equation procedure was used for cointegration analysis. The use of a single equation procedure was deemed appropriate, at least with respect to preserving the degree of freedom. Table 4 provides a summary of the results of the tests for cointegration on the residuals of the long run import duty revenue model. Overall, the results show that the errors in the cointegration regression are stationary. A comparison of the computed Augmented Dickey Fuller and Phillips-Perron (PP) test results tends to support cointegration between the tariff revenue and explanatory variables. Both tests reject the null hypothesis of no cointegration.
Table 4. Static Model: Tests for Cointegration between Import Duty Revenue (IDR) and Explanatory Variables

\begin{tabular}{|c|c|c|c|c|}
\hline \multirow{4}{*}{$\begin{array}{l}\text { Augmented } \\
\text { Dickey Fuller } \\
\text { Test on Residuals }\end{array}$} & ADF-tes & & & \multirow{3}{*}{$\begin{array}{l}\text { Order of } \\
\text { Integration }\end{array}$} \\
\hline & \multirow{2}{*}{ t-value } & \multicolumn{2}{|c|}{ Test Critical Value } & \\
\hline & & $\begin{array}{l}1 \% \\
\text { Level }\end{array}$ & $\begin{array}{l}5 \% \\
\text { Level }\end{array}$ & \\
\hline & $-3.05^{*}$ & -3.66 & -2.96 & $\mathrm{I}(0)$ \\
\hline \multirow{4}{*}{$\begin{array}{l}\text { Phillips-Perron } \\
\text { (PP) Test on } \\
\text { Residuals }\end{array}$} & PP-test & & & \multirow{3}{*}{$\begin{array}{l}\text { Order of } \\
\text { Integration }\end{array}$} \\
\hline & \multirow[t]{2}{*}{ t-value } & \multicolumn{2}{|c|}{ Test Critical Value } & \\
\hline & & $\begin{array}{l}1 \% \\
\text { Level }\end{array}$ & $5 \%$ Level & \\
\hline & $-5.48 * *$ & -4.28 & -3.56 & $\mathrm{I}(0)$ \\
\hline
\end{tabular}

Notes $(1) *(* *)$ denote rejection of the null hypothesis at $5 \%$ and $1 \%$ critical values respectively (2) Included in the test equation: (i) trend and intercept (ii) lagged difference (1) 


\subsection{Error Correction Model ${ }^{4}$}

In order to capture the short run relationship between the import duty revenue and a series of explanatory variables, the error correction model was estimated. ${ }^{5}$ The error correction specification restricts the long run behaviour of the endogenous variables to converge to their cointegrating relationships while allowing a wide range of short run dynamics. The error correction terms $(E C T)$ were obtained from the solved static long run equation and lagged once, i.e. $E C T_{t-1}$. The import duty revenue (IDR) equation was therefore specified to include the error correction model and the estimation results are presented in Table 5. The model seems to be correct as the coefficient of the error correction term is negative and statistically significant. The $E C T_{t-1}$ reflects the attempt to correct deviations from the long run equilibrium path and its coefficient can be interpreted as the speed of adjustment.

\subsection{Estimation Results and Implications}

Estimation results presented in Table 5 show that adjusted R-squared, which measures the goodness of fit of the variables, indicates that about 93 percent of the variations in the import duty revenue is explained by the explanatory variables. Similarly, the F-statistic of 48.4 rejects the null hypothesis that all explanatory variables have coefficients not different from zero. Furthermore, Durbin-Watson statistic (DW) indicates that there is no autocorrelation, as the DW statistic of 1.9 lies close to 2 .

Table 5. Empirical Results

\begin{tabular}{lllll}
\hline Variable & Coefficient & \multicolumn{1}{c}{ Std. Error } & \multicolumn{1}{c}{ t-Statistic } & Prob. \\
\hline$C$ & -0.0121 & 0.0169 & -0.720 & 0.478 \\
$C T R$ & 0.3064 & 0.0319 & $9.595^{* * * *}$ & 0.000 \\
$(C T R)^{2}$ & -0.0085 & 0.0013 & $-6.515^{* * * *}$ & 0.000 \\
$\log p c G D P$ & 0.2814 & 1.9397 & 0.145 & 0.886 \\
$R E R$ & -0.0001 & 0.0001 & -0.915 & 0.370 \\
$I M P O R T$ & 0.0912 & 0.0069 & $13.227^{* * *}$ & 0.000 \\
$C T A X$ & 0.0566 & 0.0229 & $2.463^{* *}$ & 0.022 \\
$D T A X$ & -0.1162 & 0.0354 & $-3.280^{* * *}$ & 0.003 \\
$E C T_{t-1}$ & -1.0398 & 0.2325 & $-4.470^{* * *}$ & 0.000 \\
\hline R-sq. & 0.948 & S.E. of reg. & & 0.092 \\
Adj. R-sq. & 0.929 & F-statistic & & 48.437 \\
RSS & 0.178 & Prob(F-statistic) & 0.000 \\
DW Statistic & 1.899 & & & \\
\hline
\end{tabular}

Notes: *significant at 10 percent; $* *$ Significant at 5 percent; $* * *$ Significant at 1percent.

\footnotetext{
${ }^{4}$ Error correction model is restricted model that has cointegration restrictions built into the specification, so that it is designed for use with non-stationary series that are known to be cointegrated. The cointegrating term is known as the error correction term $\left(\mathrm{ECT}_{\mathrm{t}-1}\right)$ since the deviation from the long-run equilibrium is corrected gradually through a series of partial short-run adjustments.

5 According to Angle and Granger (1987), when cointegration is established the next step is to represent a short-run disequilibrium relationship of the variables using an ECT.
}

The results also show that the coefficient of collected tariff rate $(C T R)$ is positive and significant at 1 percent indicating that one percent reduction in collected tariff rate may lead to about 0.3 percent decline in import duty revenue-to-GDP ratio. This confirms the hypothesis that a reduction in the tariff rates results in a significant loss of import duty revenue. The robust support is provided for the presence of a significant relationship between the import duty revenue-to-GDP ratio and income tax-to-GDP ratio. The coefficient of income tax-to-GDP ratio $(D T A X)$ is negative and significant at 1 percent implying that as income tax-to-GDP ratio (DTAX) increases, import duty revenue-to-GDP ratio declines. This also indicates that reduction in import duty revenue is partially replaced by income tax revenue. Despite the fact that the income tax base is mostly comprised of wages of employees in the public sector, because all other taxpayers are self-employed or small businesses who evade paying all, or most, of the income tax, the ratio of income tax revenue as percent of GDP has increased from 3.2 percent in 1993/94 percent to 5.3 percent in $2009 / 10$. This may be due to the fact that taxing individual incomes and large corporations does not involve significant administrative and compliance costs, because they are per force required to comply with statutory accounting requirements.

The coefficient of consumption taxes-to-GDP ratio is positive and significant at 5 percent. The positive relationship between indirect taxes and import duty revenue-to-GDP ratios may be due to the fact that informal sector and exemptions tend to narrow the tax base; as a result consumption indirect taxes (VAT and excises)-to-GDP ratio does not grow significantly to replace import duty revenue loss. Moreover, this result is contrary to the general advice of international institutions such as the IMF and the World Bank given to developing countries over the past few decades, that these countries need to replace import duty revenue with domestic consumption taxes, particularly value-added tax (VAT) and to maintain relatively high corporate income tax rates. The main reason for this controversy is that, while this assumption is automatically satisfied when an economy consists of only the formal sector, it is not a plausible assumption in the presence of a large informal segment in the economy that, by definition, escapes VAT coverage. Furthermore, the macroeconomic environment in Tanzania does not support revenue recovery as coefficients of percapita GDP ( $p c G D P)$ and real exchange rate $(R E R)$ are insignificant.

The coefficient of import value as a percent of GDP (IMPORT) is positive and significant at 1 percent indicating that one percent increase in import-to-GDP ratio may increase import duty revenue-to-GDP ratio by 0.09 percent. This is consistent with the theory that higher import-to-GDP ratio is seen to lead to rising shares of import duty revenue in GDP. However, due to the complex nature of Tanzania import trade like exemptions, informal trade, highly inelastic essential import, it is difficult to make conclusive remark on the magnitude of the impact of import on import tax revenue both as the percent of GDP. 
As expected, the result confirms the hypothesis that there is a diminishing revenue return to increase in the tariff rate, as the square term is negative and significant at 1 percent. Specifically the coefficient suggests that there is a revenue-maximizing tariff rate. In other words, the negative magnitude of collected tariff rate square $(C T R)^{2}$ suggests that a potential "Laffer effect" exists for trade tax revenue. ${ }^{6}$ This also confirms that for a given value of imports declared to customs, smuggling and the ratio of imports coming in with exemption increase as the tariff rate increases. This is because first, the value of imports coming in under non-exemptions decreases while the value coming in under exemption remains constant. Second, the incentive to lobby for exemption increases with the level of tariff.

\section{Conclusions}

The purpose of this study was to examine the impact of trade liberalization proxied by reduction in collected tariff rate and other determinants of tax revenue that are associated with trade liberalization and reforms. In estimating the import duty revenue model, cointegration analysis and error correction modeling were applied. The study findings showed that trade liberalization is a potential source of fiscal instability in Tanzania because it relies heavily on revenue from international trade. Trade liberalization eventually results in reduced import duty revenue and, hence, will raise difficult fiscal issues if appropriate steps have not been taken to strengthen the domestic tax system. This implies that implementing comprehensive reform of the domestic tax system from the outset of liberalization should be viewed a priority.

Because Tanzania relies on the international trade taxes for a large share of its total revenue, the policy challenge is how to maintain fiscal stability under trade liberalization. The experience of industrial economies shows that at advanced stages of economic development the revenue side of the budget can be structured in such a way to achieve a stable fiscal position even with negligible import duty revenues. Therefore, it is possible that indirect effects operating through higher levels of income and openness associated with trade reform have more than offset the direct loss of revenue. However, this is complicated in Tanzania because of limited economic base and ability to tax it. The tax base in Tanzania tends to be narrow, excluding relatively important sectors in the economy that are not fully monetized or incorporated in the formal economy, such as large segments of agriculture, small-scale trade and services.

In Tanzania, the consumption tax revenues (excises and

\footnotetext{
${ }^{6}$. The Laffer curve suggests that, as taxes increase from low levels, tax revenue collected by the government also increases. For example, for income tax, the curve shows that tax rates increasing after a certain point would cause people not to work as hard or not at all, thereby reducing tax revenue. Eventually, if tax rates reached 100 percent (the far right of the curve), then all people would choose not to work because everything they earned would go to the government.
}

VAT) have not improved to recoup revenue loss from trade liberalization. There are, however, several low income countries that have recovered import duty revenue loss from domestic sources, and their experience provides useful lessons for Tanzania. It suggests, in particular, that strengthening the domestic consumption tax system, through the excises and, in particular by means of a simple, broad-based VAT, has a crucial role to play; and in contrast to the standard theoretical prescription that consumption taxes take the burden of revenue recovery, the strengthening of income tax can also make an important contribution. ${ }^{7}$ This strategy, focused on a shift towards domestic consumption taxes, has considerable practical merit.

Direct tax revenue can also be increased through strengthening the tax collection system and eliminating tax holidays and other exemptions. The personal income tax should be characterized by only a few brackets and a moderate top marginal rate by limited personal exemptions and deductions. The corporate income tax should be levied at moderate rate, tax incentives should be avoided, and depreciation allowances should be uniform across sectors. Furthermore, fiscal stability during trade liberalization requires a stable macroeconomic environment, with low and predictable inflation, steady growth in per capita GDP, and appropriate exchange rate policies.

JEL Classification: F10, F13, H20, H25

\section{Acknowledgements}

The author thanks Prof. Nehemiah Osoro and Prof. Michael O. Ndanshau for their valuable comments.

\section{References}

[1] African Development Bank Group (2010), "Domestic Revenue Mobilization for Poverty Reduction in East Africa: The Tanzania Case Study," Regional Department East Africa (OREA).

[2] Agbeyegbe, T., J. Stotsky, and A. Wolde Marian (2003), "Trade Liberalization, Exchange Rate Changes, and Tax Revenue in sub-Saharan Africa," Paper Presented at the Ad-Hoc Expert Group Meeting on Maintaining the Government Fiscal Base in the Context of Trade Liberalization, United Nations Economic Commission for Africa, Addis Ababa, October.

[3] Amponsah, A. W. (2002), "Analytical and Empirical Evidence of Trade Policy Effects of Regional Integration: Implications for Africa," Trade Policy, Africa Development Forum III, March 3-8, Addis Ababa, Ethiopia.

[4] Arellano, M. and S. Bond (1991), "Some Tests of Specification for Panel Data: Monte Carlo Evidence and an Application to Employment Equations." The Review of Economic Studies, 58. pp. 277 - 297.

\footnotetext{
${ }^{7}$ These issues are discussed at length in Ebrill, Stotsky, and Gropp (1999), Agbeyegbe, Stotsky, and WoldeMariam (2004), and Khattry and Rao (2002).
} 
[5] Baunsgaard, T. and M. Keen (2005), "Tax Revenue and (or?) Trade Liberalization," IMF Working Paper, IMF, Fiscal Affairs Department.

[6] Blejer, M., and A. Cheasty (1990), "Fiscal Implications of Trade Liberalization," in V. Tanzi (ed), Fiscal Policy in Open Developing Economies, Washington D.C. International Monetary Fund, pp. 66-81.

[7] Chelliah, Raja J. (1971), "Tax Reforms Committee Reports," Interim (1991), Parts I (1992) and II (1993).

[8] Charemza, W.W. and D. F. Deadman (1992), New Directions in Econometric Practice, Edward Elgar, England.

[9] Di John, J. (2010), "The Political Economy of Taxation and State Resilience of in Zambia since 1990," Crisis Study Working Paper (Series 2) 75, London; London School of Economics.

[10] Dollar, David and Kraay Art (2001), "Trade, Growth, and Poverty," World Bank Research Paper. Vol. 38 (3).

[11] Ebrill, L., J. Stotsky, and R. Gropp (1999) "Revenue Implications of Trade Liberalization," International Monetary Fund Occasional Paper, No. 180, Washington D.C.

[12] Engle, R. F. and C. W. J. Granger (1987) "Cointegration and Error Correction: Representation, Estimation and Testing", Econometrica, 55, 251-76.

[13] Escolano Julio (1995), "International Trade Taxes," in Tax Policy Handbook, edited by Parthasarathi Shome (Washington: International Monetary fund.)

[14] Farhadian-Lorie, Ziba, and Menachem Katz (1989), "Fiscal Dimesions of Trade Policy," in Fiscal Policy, Stabilization, and Growth in Developing Countries, ed. by Mario I. Blejer and Key-young Chu (Washinton), International Monetary Fund, pp. 276-306.

[15] Fukasaku, K. (2003), "Fiscal Impact of Trade Liberalization: A Review of Recent Country Experience in Africa," UNECA, Addis Abba.

[16] International Monetary Fund (IMF) (2003), “Adjustment in IMF-Supported Programmes,” IMF Washington.

[17] International Monetary Fund (IMF), "Government Finance Statistics Yearbook," assorted issues.

[18] International Monetary Fund (IMF), (2005), "Dealing with the Revenue Consequences of Trade Reform," Fiscal Affairs Department, IMF.

[19] Johansen, S. (1988), "Statistical Analysis of Cointegration Vectors," Journal of Economic Dynamic and Control, 12: 231-254

[20] Johansen, S. and K. SJuselius (1990) “Maximum Likelihood
Estimation and Inference on Cointegration: with Application to the Demand for Money", Oxford Bulletin of Economics and Statistics, 52, 169-210.

[21] Khattry, Barsha and Mohan Rao (2002), "Fiscal Faux Pas?: An Analysis of Revenue Implication of Trade Liberalization," World Development, Vol. 30, No. 8, pp. 1431-1444.

[22] Kubota, K. (2000), "Fiscal Constraints, Collection costs, and Trade Policies," Policy Research Working Paper No. 2366, World Bank, NewYork.

[23] Matlanyane, Adelaide and Chris Harmse (2001), "Revenue Implications of Trade Liberalization in South Africa," University of Pretoria, South Africa.

[24] McLaren, J. (1998), "Black Markets and Optimal Evadable Taxation”, Economic Journal, Vol. 108 (448), pp. 665-679.

[25] Paudel, Dandapani (2006), "Revenue Implications of WTO Regime and Alternative Measures for Revenue Mobilization," Economic Policy Network, Policy Paper 29.

[26] Pritchett, Lant, and Geeta Sethi (1994), "Tariff Rates, Tariff Revenues, and Tariff Reform: Some New Facts," World Bank Economic Review, No.8 (1), pp.1-16.

[27] Rodrik, Dani (2001), "Trading in Illusions," Foreign Policy, March/April.

[28] Rodrik, Dani, (1995), "Trade Strategy, Investment, and Exports: Another Look at East Asia," NBER Working Papers No. 5339, National Bureau of Economic Research, Inc.

[29] Stock, J.H. (1987) "Asymptotic Properties of Least Squares Estimators of Cointegrating Vectors", Econometrica, 56, 1035-56.

[30] Tanzania Revenue Authority (TRA) (various), Revenue Performance Reports, Dar es Salaam: Tanzania Revenue Authority.

[31] Tanzi, Vito (1989), “The Impact of Macroeconomic Policies on the Level of Taxation and the Fiscal Balance in Developing Countries," The International Monetary Fund, Staff Paper, Vol. 36, pp. 633-56.

[32] UNECA (2004), Economic Report on Africa, United Nations Economic Commission for Africa, Addis Ababa.

[33] World Bank (2002), "Tanzania at the Turn of Century: Background Papers, and Statistics,” World Bank, 2002.

[34] World Trade Organization (2003), "Adjusting to Trade Liberalization: The Role of Policy, Institutions, and WTO Disciplines," Paper No. 15.

[35] World Trade Organization (2003), "Revenue Implications of Trade Liberalization," Negotiating Group on Market Access, TN/MA/W/18/Add.2, April. 